\title{
Inhaled Pollutants: The Molecular Scene behind Respiratory and Systemic Diseases Associated with Ultrafine Particulate Matter
}

\author{
Hussein Traboulsi ${ }^{1}$, Necola Guerrina ${ }^{2}$, Matthew Iu ${ }^{1}$, Dusica Maysinger ${ }^{3}$, Parisa Ariya ${ }^{4}$ and \\ Carolyn J. Baglole ${ }^{1,2,3, *}$ \\ 1 Department of Medicine, McGill University, Montreal, QC H4A 3J1, Canada; \\ Hussein.Traboulsi@mail.mcgill.ca (H.T.); matthew.iu@mail.mcgill.ca (M.I.) \\ 2 Department of Pathology, McGill University, Montreal, QC H4A 3J1, Canada; \\ Necola.guerrina@mail.mcgill.ca \\ 3 Department of Pharmacology \& Therapeutics, McGill University, Montreal, QC H3G 1Y6, Canada; \\ Dusica.maysinger@mcgill.ca \\ 4 Department of Chemistry, McGill University, Montreal, QC H3A 2K6, Canada; parisa.ariya@mcgill.ca \\ * Correspondence: Carolyn.baglole@mcgill.ca; Tel.: +1-514-934-1934
}

Academic Editors: Paul R. Reynolds and Benjamin T. Bikman

Received: 21 November 2016; Accepted: 13 January 2017; Published: 24 January 2017

\begin{abstract}
Air pollution of anthropogenic origin is largely from the combustion of biomass (e.g., wood), fossil fuels (e.g., cars and trucks), incinerators, landfills, agricultural activities and tobacco smoke. Air pollution is a complex mixture that varies in space and time, and contains hundreds of compounds including volatile organic compounds (e.g., benzene), metals, sulphur and nitrogen oxides, ozone and particulate matter (PM). $\mathrm{PM}_{0.1}$ (ultrafine particles (UFP)), those particles with a diameter less than $100 \mathrm{~nm}$ (includes nanoparticles (NP)) are considered especially dangerous to human health and may contribute significantly to the development of numerous respiratory and cardiovascular diseases such as chronic obstructive pulmonary disease (COPD) and atherosclerosis. Some of the pathogenic mechanisms through which $\mathrm{PM}_{0.1}$ may contribute to chronic disease is their ability to induce inflammation, oxidative stress and cell death by molecular mechanisms that include transcription factors such as nuclear factor $\mathrm{\kappa B}(\mathrm{NF}-\mathrm{KB})$ and nuclear factor (erythroid-derived 2)-like 2 (Nrf2). Epigenetic mechanisms including non-coding RNA (ncRNA) may also contribute towards the development of chronic disease associated with exposure to $\mathrm{PM}_{0.1}$. This paper highlights emerging molecular concepts associated with inhalational exposure to $\mathrm{PM}_{0.1}$ and their ability to contribute to chronic respiratory and systemic disease.
\end{abstract}

Keywords: air pollution; epigenetics; chronic obstructive pulmonary disease; particulate matter; aryl hydrocarbon receptor; nuclear factor- $\mathrm{kB}$

\section{Introduction}

Air pollutants are released into the atmosphere and can cause significant harm to humans. According to the World Health Organization (WHO), around 3.5 million people die each year because of urban and indoor air pollution, making this a leading environmental health risk. Air pollution is now recognized as a human carcinogen and is regarded as major risk factor for acute and chronic diseases including cardiovascular disease (CVD), liver fibrosis and chronic respiratory diseases such as asthma and chronic obstructive pulmonary disease (COPD). More than $25 \%$ of premature deaths associated with air pollution are respiratory in nature [1].

The sources of air pollution are numerous and include anthropogenic sources such as transportation (e.g., vehicle exhaust), factory emissions (e.g., industries, coal-fired power plants), 
combustion (e.g., biomass, cigarette smoke) and agriculture (e.g., fertilizer and animal waste). Air pollution can also come from natural sources such as volcanoes, forest fires and dust storms. Regardless of the origin, air pollution is a toxic mixture of gases and particulate matter (PM) composed of organic chemicals (polycyclic aromatic hydrocarbons (PAH)), metals (iron, nickel), gases (ozone), biological agents (plant pollen, endotoxins, bacteria) and minerals (quartz, asbestos) [2,3]. The main gaseous contaminants are carbon monoxide and dioxide $\left(\mathrm{CO}\right.$ and $\mathrm{CO}_{2}$ respectively), nitrogen dioxide $\left(\mathrm{NO}_{2}\right)$, ozone $\left(\mathrm{O}_{3}\right)$ and sulfur dioxide $\left(\mathrm{SO}_{2}\right)$. Other important gaseous pollutants are ammonia and volatile organic compounds (VOCs; e.g., methane, benzene and chlorofluorocarbon). It is the inhalation of PM that is often associated with increased morbidity and mortality, the collective incidence and severity of which are strongly influenced by the duration and amount of PM exposure [4]. According to the WHO, it is estimated that exposure to PM causes about $16 \%$ of lung cancer deaths, $11 \%$ of COPD deaths, and more than $20 \%$ of ischaemic heart disease and stroke. PM is a complex airborne mixture of solid, liquid or mixed-phase particles composed of organic, inorganic and organometallic compounds suspended in air, and its composition varies in space and time. In terms of aerodynamic diameter, PM can be classified according to their size: $\mathrm{PM}_{10}$ : coarse particles less than $10 \mu \mathrm{m}$ in diameter; $\mathrm{PM}_{2.5}$ : fine particles less than $2.5 \mu \mathrm{m}$; and $\mathrm{PM}_{0.1}$ : ultrafine particles (UFPs) smaller than $100 \mathrm{~nm}$, which includes the nanoparticles (NPs). Of these, $\mathrm{PM}_{0.1}$ have the potential to exert significant harm, as particles of this size can escape broncho-mucociliary action and scavenging by alveolar macrophages. These particles also penetrate deep into the respiratory tract (i.e., the alveolus) where they can be absorbed by the blood stream. Deposition patterns have revealed that the lungs are the primary target, although particles could be detected in other organs like the liver, kidney, heart and brain [5]. Studies in healthy human volunteers using Technegas, an ultrafine dispersion of Technetium-labelled carbon (99 mTc) particles approximately $4-20 \mathrm{~nm}$ in diameter, revealed that the $\mathrm{PM}_{0.1}$ remained in the lung up to $6 \mathrm{~h}$ after installation although some were detected in the blood immediately after inhalation [6]. Furthermore, these particles have a very large effective surface area where chemical interactions can occur and may be important biologically, as $\mathrm{PM}_{0.1}$ cross cell membranes and directly interact with cellular structures. Indeed, animal and in vitro studies have shown that acute exposures to $\mathrm{PM}_{0.1}$ may cause changes in lung function and airway inflammation, and could enhance allergic responses, increase vascular thrombogenic effects, alter endothelial function, affect heart rate variability and accelerate atherosclerosis [7].

During the last decade, it has become increasingly clear that the health impacts of $\mathrm{PM}_{0.1}$ are significantly affected by physical and chemical processes such as size, gas-particle partitioning, hygroscopicity, liquid-liquid phase separation, redox kinetics, surface tension, viscosity, molecular configuration, active sites, surface properties, and chemical composition. Although there is increasing assumption that $\mathrm{PM}_{0.1}$ are deleterious to human health, very little is known about the cellular, molecular and genetic/epigenetic alterations that may affect the incidence/severity of chronic disease in individuals exposed to $\mathrm{PM}_{0.1}$. In this review, we highlight emerging evidence of key biological and signal transduction pathways that trigger inflammation and oxidative stress in response to $\mathrm{PM}_{0.1}$ exposure as important contributors to the development of chronic respiratory and CVD (Figure 1). 


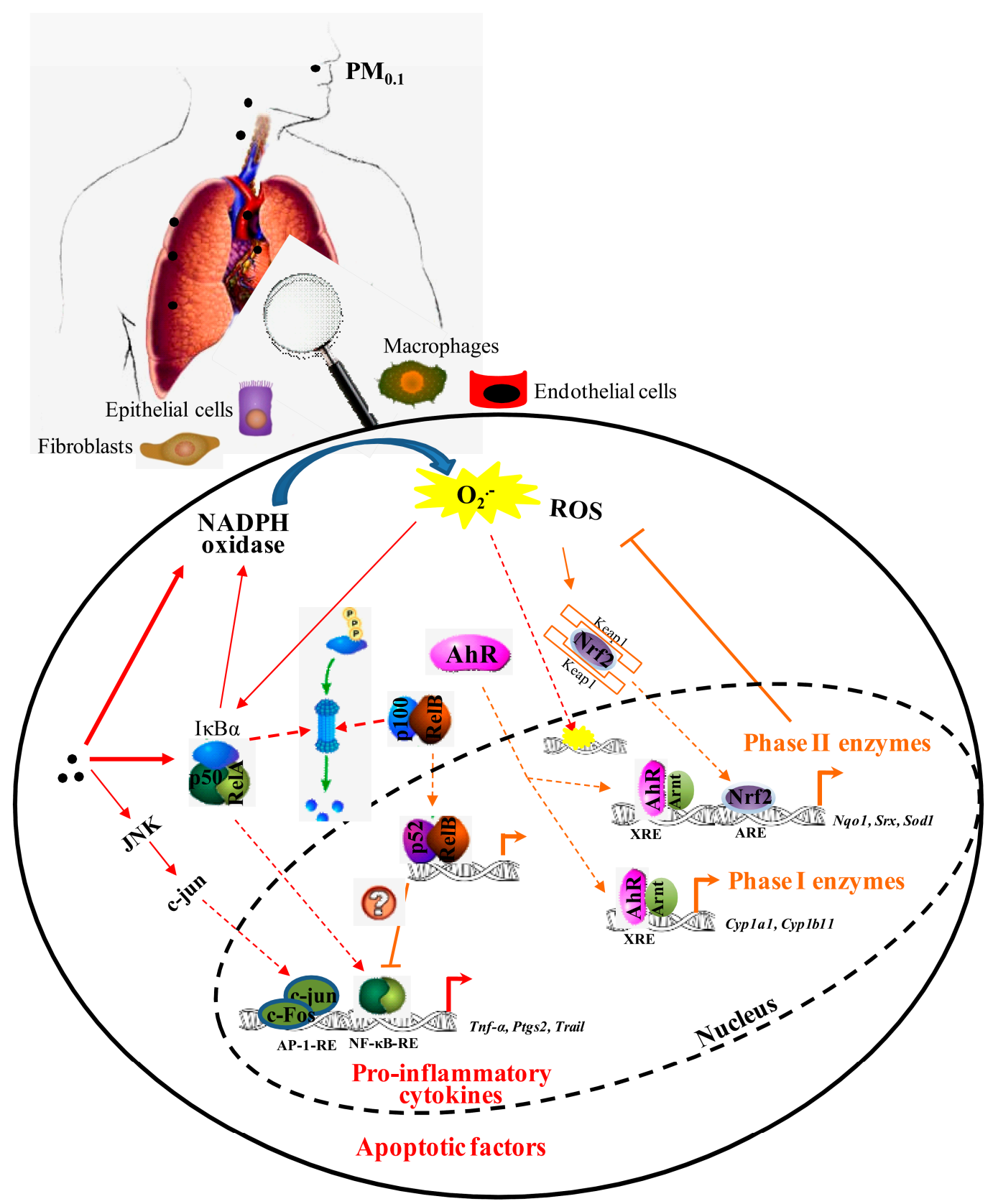

Figure 1. The molecular mechanisms associated with inflammatory and oxidative stress in response to chronic exposure to $\mathrm{PM}_{0.1}$. PM, particulate matter; ROS, generation of reactive oxygen; JNK, c-Jun kinase; AhR, Aryl hydrocarbon receptor; Nrf2, nuclear factor (erythroid-derived 2)-like 2; ARE, antioxidant response element; XRE, xenobiotic response element; AP-1-RE, AP-1 response element; NF- $\mathrm{B}-\mathrm{RE}, \mathrm{NF}-\kappa \mathrm{B}$ response element; RelA, v-rel avian reticuloendotheliosis viral oncogene homolog A or p65; RelB, reticuloendotheliosis viral oncogene homologue $\mathrm{B}$; NADPH, nicotinamide adenine dinucleotide phosphate-oxidase; Arnt, aryl hydrocarbon receptor nuclear translocator. Solid line: activation; dashed line: translocation; red line: inflammatory/oxidant pathway; red dashed line: anti-inflammatory/ anti-oxidant pathway.

\section{Pathogenic Processes Implicated Following Inhalation of $\mathbf{P M}_{0.1}$}

\subsection{Inflammation}

Acute inflammation is a self-limiting response to tissue injury [8] or can be part of the host response to invading pathogens [9]. Inflammation is induced by stress (chemical, physical), bacteria 
and viruses or environmental pollutants (e.g., cigarette smoke, air pollution) [10,11]. However, the persistence of initiating factors and/or inadequate resolution of the inflammatory response can itself lead to tissue damage and thus drives many pathogenic processes including carcinogenesis and autoimmunity [9]. The ability of PM to induce an inflammatory response is dependent on a number of factors, including the size, although particles of all sizes are capable of inducing an inflammatory response [12]. However, the dependence on size alone for overall toxicity-including inflammation-is varied. Some in vitro studies have indicated that smaller particles (those near the $\mathrm{PM}_{0.1}$ range) induced a strong inflammatory response compared to larger particles $[13,14]$. Other studies have indicated that $\mathrm{PM}_{10}$ with higher endotoxin elicit higher cytokine secretion compared to $\mathrm{PM}_{2.5}$ [15], indicating that endotoxin may be a more important determinant. The nature of the inflammatory response may also differ, depending on the particle size. While all sizes (coarse, fine and ultrafine) induced IL-8 release from A549 cells, particles in the fine and ultrafine category induced higher IL-6 compared to coarse particles [12].

Inhalational exposure to $\mathrm{PM}_{0.1}$ is commonly associated with enhanced pulmonary inflammation that is characterized by the rapid influx of neutrophils and induction of pro-inflammatory cytokines. $\mathrm{PM}_{0.1}$ can also reach the alveolar region, which is the primary site of gas exchange in the lung [16]. It is noteworthy that atherosclerotic plaque formation in mice is enhanced by exposure to ambient $\mathrm{PM}_{0.1}$ due in part to the promotion of systemic pro-inflammatory mediators [17], an effect that may be due to direct activation of endothelial cells [18]. $\mathrm{PM}_{0.1}$ of particular interest include cerium oxide $\left(\mathrm{CeO}_{2}\right)$, a NP often added to diesel fuel to increase burning efficiency, is now associated with adverse health outcomes. Inhalational exposure of $\mathrm{CeO}_{2}$ to $\mathrm{CD} 1$ mice significantly increased lung neutrophils and the pro-inflammatory cytokines tumor necrosis factor- $\alpha$ (TNF- $\alpha$ ) and interlekin- $1 \beta$ (IL-1 $\beta$ ) [5]. Sub-acute inhalation of $\mathrm{PM}_{0.1}$ also increases pulmonary inflammation in mice and is thought to be a starting point for long-term cardio-pulmonary health effects [19]. The effects of $\mathrm{PM}_{0.1}$ may extend beyond their ability to incite inflammation, and lead to significant impairment of recruited and resident inflammatory cells. For example, exposure of human alveolar macrophages to $\mathrm{PM}_{0.1}$ impairs their phagocytic ability, which may increase susceptibility to infections in those with underlying disease (e.g., asthma, COPD) [20].

\subsection{Oxidative Stress and Antioxidant Defense}

Oxidative stress and inflammation are closely related processes that can be induced by each other. Oxidative stress arises from an imbalance between oxidants and antioxidants that ultimately lead to the generation of reactive oxygen (ROS) and reactive nitrogen species (RNS) [21]. ROS are a class of molecules deprived of a complete electron pair and include free radicals and oxidants [21]. Free radicals are generally small molecules with an unpaired electron in the outer valance and include the superoxide anion $\left(\mathrm{O}_{2}{ }^{-}\right)$, hydroxyl radical $(\bullet \mathrm{OH})$ and hydrogen peroxide. ROS are produced by all aerobic organisms during cellular respiration. In immune cells, such as neutrophils and mast cells, there is a respiratory burst and hence increased release of ROS. Oxidative stress is one of the most common cellular outcomes associated with $\mathrm{PM}_{0.1}$ toxicity. Increased ROS due to exposure to $\mathrm{PM}_{0.1}$ have been shown in various cell types, including those of the respiratory system such as normal bronchial epithelial cells (NHBE) [22], Beas-2B [23-25], A549 [22] and human lung fibroblasts [26,27]; those with relevance to cardiovascular disease include human umbilical vein and human aorta endothelial cells (HUVEC/HAEC) [28,29] and macrophages [30]. Exposure of mouse pulmonary microvascular endothelial cells to an ambient $\mathrm{PM}_{0.1}$-with or without cigarette smoke extract (CSE) - induced oxidative stress that activated the mitogen-activated protein kinases (MAPKs) to induce the pro-inflammatory cytokine IL-6 [31]. $\mathrm{PM}_{0.1}$ are the most potent at inducing oxidative stress compared to coarse and fine particles; due to their small size, they can enter the cell and damage the mitochondria, leading to ROS production [32].

Because they are highly reactive, ROS can damage key cellular components such as DNA, proteins, mitochondria and lipids. Thus, if cellular repair mechanisms cannot compensate for the 
excess oxidative stress and consequent cellular damage, then cell death can occur by necrosis (non-physiological) or apoptosis (programmed cell death) [33]. Indeed, exposure to $\mathrm{PM}_{0.1}$ increases oxidative stress and DNA damage with no compensatory upregulation of DNA repair in elderly populations [34] and neonatal animals [35], indicating the potential for disease in susceptible populations [36]. The production of ROS are counter-balanced with biochemical antioxidants [37]. A crucial part of the antioxidant system includes glutathione (GSH), a nonprotein tripeptide assembled from cysteine, glutamic acid and glycine via the enzymes glutamate cysteine ligase (GCL) and glutathione synthetase. Thiol groups present on the cysteinyl moiety of GSH react with oxidants and oxidized proteins, thereby detoxifying them. This reaction generates an oxidized dimer of GSH-GSSG that is reduced back to GSH by glutathione reductase. GSH participates in many important antioxidant defense pathways including the detoxification of superoxide $\left(\mathrm{O}_{2}{ }^{-}\right)$via the enzyme superoxide dismutase (SOD). Indeed, there are significant perturbations in GSH levels with exposure to $\mathrm{PM}_{0.1}[38,39]$. Thus, an oxidant-antioxidant imbalance can lead to significant alterations within the cell that can culminate in enhanced cell death mechanisms.

\subsection{Cell Death Pathways}

\subsubsection{Necrosis}

Among the most commonly reported modes of cell death related to PM exposure are necrosis, apoptosis and necroptosis. Necrosis is characterized by cell swelling and loss of membrane integrity that has recently been classified as regulated necrotic cell death (necroptosis) and accidental cell death (necrosis) [40]. Necroptosis reflects both the programmed nature of this pathway, which shares characteristics with apoptosis (see below) and its necrotic morphological features, namely swelling and lysis of the cell. Necroptosis signaling involves the kinase activity and subsequent physical interaction of receptor interacting protein kinases 1 and 3 (RIPK1/RIPK3) to form the necrosome, which then subsequently mediates the phosphorylation of mixed lineage kinase domain-like proteins (MLKL). Following their activation, p-MLKLs then dimerize, subsequently interacting with, and establishing, ion channels in the cell membrane, thus enhancing permeability that results in cell swelling and lysis. There have been several reports of $\mathrm{PM}_{0.1}$-induced necrotic cell death. Foldbjerg and colleagues [41] observed that upon treatment of a human monocytic cell line (THP-1 cells) with polyvinyl pyrrolidone-coated silver NPs (AgNPs), higher doses $(>2500 \mathrm{mg} / \mathrm{mL})$ induced necrotic cell death whereas lower doses $(<2500 \mu \mathrm{g} / \mathrm{mL})$ induced apoptosis. Similar to this, Pan and colleagues (2009) observed that the size of the gold NPs determines both their toxicity as well as the cell death mechanism [42]. Here, exposure to smaller AuNPs (1.4 nm in diameter) were significantly more cytotoxic, inducing oxidative stress and ultimately necrotic cell death, whereas larger AuNPs (15 nm in diameter) were deemed non-toxic and associated with apoptotic cell death.

\subsubsection{Apoptosis}

Apoptosis is a tightly regulated molecular process morphologically associated with cellular fragmentation, membrane blebbing and shrinkage. Apoptosis is necessary during development, cell turnover, and immune system regulation. Dysregulation of apoptosis has been implicated in disease etiology, and in particular, during the emphysematous component of COPD. $\mathrm{PM}_{0.1}$ directly affect cell apoptosis. In the human alveolar epithelial cell line A549, treatment with a soluble fraction of ambient $\mathrm{PM}_{0.1}$ induced high levels of ROS and consequent apoptosis [43]. Apoptosis can occur through the extrinsic or intrinsic pathways. The extrinsic pathway begins by activation of a "death receptor" by soluble cytokines such as tumor necrosis factor- $\alpha$ (TNF- $\alpha$ ) to promote a "pro-death" pathway through c-Jun and the processing of pro-caspase 8 into caspase- 8 , where it cleaves caspase-3, a key executor of apoptosis. The intrinsic pathway involves the mitochondria, where there is disruption in mitochondrial membrane potential and release of cytochrome $C$, which activates caspases. The BAX family of proteins sense mitochondrial health, and execute the apoptotic cascade when mitochondrial 
membrane potential drops. Bcl-2, which gates the mitochondria, is downregulated by Bax allowing cytochrome $\mathrm{C}$ to translocate from the mitochondria into the cytoplasmic space. The translocation of cytochrome $C$ is a critical event that triggers the activation of caspase- 9 , which leads to caspase- 3 activation. Thus, activation of caspase- 3 results in catalytic processing, and cleaved caspase- 3 then coordinates the degradation of proteins involved in cellular assembly and repair including poly (ADP-ribose) polymerase (PARP) and lamin A/C. There is evidence for apoptosis upon exposure to $\mathrm{PM}_{0.1}$. Exposure of rat epithelial lung cells to carbon black (in diesel engine emissions and forest fires) induces apoptosis through activation of c-Jun kinase (JNK), a kinase that phosphorylates the apoptotic factor c-Jun [44]. This effect can be seen in vivo, where exposure in mice to ultrafine colloidal silica particles (UFCSs) increases markers of oxidative stress and apoptosis [45].

\subsection{Autophagy}

Autophagy is a form of programmed cell that involves the cytoplasmic uptake and subsequent lysosomal degradation of damaged protein, substrate and organelles. In response to ATP depletion, numerous autophagy-related (Atg) proteins are activated and recruited to the pre-autophagosomal structure (PAS), which initiates the formation of a double membraned autophagic vacuole (AVI) known as the autophagosome. During maturation, the autophagosome and its enveloped cargo undergo a fusion event with a lysosome, rendering the newly synthesized structure an autophagolysosome (AVII) [46]. Dysregulation of autophagy is implicated in many diseases, and there are numerous examples of $\mathrm{PM}_{0.1}$ inducing autophagy. Ceria NPs and quantum dot nanocrystals have been considered inducers of autophagy $[47,48]$. Li and colleagues, for example, illustrated that human lung fibroblasts are able to internalize these AuNPs, which subsequently induce oxidative stress and autophagy [49]. In a recent study, blockage of autophagy reduced the expression of inflammatory cytokines in mouse airways exposed to $\mathrm{PM}_{0.1}$. This study also demonstrated that mice with impaired autophagy had significantly reduced airway inflammation and mucus hyper-production in response to the $\mathrm{PM}_{0.1}$, suggesting that autophagy contributes to PM-induced airway epithelial injury and inflammation [50].

\section{Signal Transduction Pathways Implicated in $\mathbf{P M}_{0.1}$-Induced Inflammation and Cell Death}

\subsection{Nuclear Factor- $\kappa B(N F-\kappa B)$}

NF-kB is composed of five proteins: p65 (RelA), p50 (NF-kB1), p52 (NF-kB2), c-Rel and RelB [51]. The classic NF- $\kappa B$ pathway is composed of p65/p50 heterodimers, where in response to inflammatory stimuli, including cigarette smoke, this heterodimer translocates to the nucleus to increase inflammatory protein expression [52]. Therefore, the NF- $\mathrm{KB}$ pathway is of potential importance in $\mathrm{PM}_{0.1}$-induced toxicity. In HUVECs for example, silica NPs induced ROS production and downstream activation of NF- $\mathrm{KB}$, which ultimately caused apoptotic cell death and the release of inflammatory cytokines [53]. Cu-NPs also increased phosphorylation of IкB $\alpha$ and p65 in vivo, indicators of activation, in the liver [54]. In a study in mouse macrophages, Nishanth and colleagues evaluated the inflammatory response to various $\mathrm{PM}_{0.1}$ including $\mathrm{Ag}$, aluminum (AI), carbon black, carbon-coated $\mathrm{Ag}(\mathrm{CAg})$ and $\mathrm{Au}$, and describe the capability of these $\mathrm{PM}_{0.1}$ to increase the expression of IL-6 and COX-2 and induced nuclear translocation of NF- $\mathrm{KB}$ [55]. Exposure to $\mathrm{ZnO}$ to human bronchial epithelial cells increased IL-8 production, a pro-inflammatory cytokine that promotes the recruitment of neutrophils to target organs, in an NF-KB-dependent manner [56]. The ability of $\mathrm{PM}_{0.1}$ to activate NF- $\mathrm{KB}$ may be due in large part to their ability to generate ROS production, as pretreatment with the antioxidant and glutathione precursors $N$-acetyl-L cysteine (NAC) blunts NF- $\mathrm{KB}$ activation [55]. The effect of the $\mathrm{PM}_{0.1}$ on NF- $\mathrm{kB}$ activity may also depend on the interaction with other agents. Although AuNP, for example, increases NF- $\kappa B$ activity, when combined with a toll-like receptor 9 (TLR9) ligand, there is suppression of NF- $\mathrm{BB}$ activity and subsequent TNF- $\alpha$ production [57]. Thus, in addition to inflammation-enhancing effects, impairment of innate immunity by $\mathrm{PM}_{0.1}$ via the NF-KB pathway should also be considered. In this context, pre-exposure of mice to carbon black 
decreased RSV virus-induced expression of TNF- $\alpha$, inducible protein (IP-10) and interferon $\gamma$ (IFN- $\gamma$ ) but increased the expression of the Th2 cytokine interleukin (IL)-13 in the lungs of RSV infected mice, suggesting that pre-exposure to $\mathrm{PM}_{0.1}$ induces an inflammatory Th2 environment rather than Th1, thereby promoting an allergic immune response rather than one for microbial defense.

Activation of the canonical (RelA/p65) pathway also increases RelB expression [58], a REL protein of the alternative NF- $\kappa B$ pathway. The alternative NF- $\kappa B$ pathway is made of $p 52 /$ RelB proteins. RelB is sequestered in the cytosol by $\mathrm{p} 100$ that is processed to $\mathrm{p} 52$, which releases $\mathrm{p} 52 / \mathrm{RelB}$ heterodimers, which then translocate to the nucleus [59]. The biological functions of the alternative NF- $\mathrm{KB}$ pathway are diverse and include thymic and secondary lymphoid organogenesis as well as B cell development [60]. The regulation of the alternative NF- $\kappa B$ pathway can occur via stabilization of NIK, which increases NIK expression to allow efficient processing of p100 to p52 [61]. Inflammatory stimuli can also increase RelB expression, nuclear localization $[11,58,62]$ or cleavage of RelB $[63,64]$, which may be how RelB controls inflammation in the liver and lung $[65,66]$. RelB potently controls pulmonary inflammation in response to cigarette smoke [67]. By increasing pulmonary RelB via adenoviral delivery, we were able to demonstrate the importance of RelB in reducing neutrophilia in response to cigarette smoke inhalation [67]. At the time of this writing, there were no published reports on the regulation of the non-canonical (RelB) NF-kB pathway by $\mathrm{PM}_{0.1}$.

\subsection{Aryl Hydrocarbon Receptor (AhR)}

The AhR is well known to mediate the toxic effects of the man-made environmental contaminant 2,3,7,8-tetrachlorodibenzo-p-dioxin (TCDD; dioxin). When the AhR binds to dioxin, the AhR disassociates from its chaperones (e.g., hepatitis B virus X-associated protein 2 (XAP2), heat shock protein 90 (Hsp90)), translocates to the nucleus and heterodimerizes with the aryl hydrocarbon receptor nuclear translocator (Arnt), followed by binding to DNA sequences termed the dioxin response elements (DRE). This sequence of events leads to the transcription of cytochrome P450 enzymes such as CYP1A1 and CYP1B1 as well as the aryl hydrocarbon receptor repressor (AHRR). The AHRR is a negative regulator of its own pathway by inhibiting AhR function through competing with the AhR for dimerization with Arnt $[68,69]$. The involvement of the $A h R$ in $\mathrm{PM}_{0.1}$ pathology is not yet clear. Although we have shown that the AhR protects against cigarette smoke-induced pulmonary oxidative stress, apoptosis and inflammation [11,70-72], and that cigarette smoke contains large amounts of $\mathrm{PM}_{0.1}$ [73], we cannot ascribe a protective function regarding protection against $\mathrm{PM}_{0.1}$ in smoke. However, premixed flame and environmental particles (PFP 70-nm) cause lung cytotoxicity in neonatal animals, which have less expression of CYP1A1 and CYP1B1, also suggesting a protective role for the AhR against environmental $\mathrm{PM}_{0.1}$ exposure [74].

\subsection{Nuclear Factor (Erythroid-Derived 2)-Like 2 (Nrf2)}

Nrf2 is a transcription factor that facilitates the transcription of a battery of genes for antioxidant and phase II metabolic defense including heme oxygenase-1 (HO-1), superoxide dismutase-1 (Sod1), sulfiredoxin-1 (Srxn1) and NAD(P)H:quinone oxidoreductases (Nqo1) [10]. Nrf2 is held in the cytoplasm by its repressor kelch-like associated protein 1 (Keap1), which ubiquitinates Nrf2 for proteosomic degradation. As such, in the absence of stress, Nrf2 has a short half-life (10-30 min) and is expressed at low levels due to continual proteolytic degradation. Upon oxidative insult, however, thiol groups on Keap1 are oxidized, liberating Nrf2 and allowing for its nuclear translocation. After dimerization with MAF, Nrf2 binds to a specific sequence of DNA known as the antioxidant response element (ARE) present in the promoter regions of genes that code for antioxidant and phase II detoxifying enzymes. Dysregulation of Nrf2 expression and function, concomitant with heightened oxidative stress, has been implicated for many chronic diseases including COPD. Metal $\mathrm{PM}_{0.1}$, including $\mathrm{Ag}, \mathrm{Au}, \mathrm{NiO}, \mathrm{TiO}_{2}$ and $\mathrm{CeO}_{2}$, have been investigated for their ability to induce oxidative stress in association with the regulation of $\mathrm{Nrf} 2$. In Beas- $2 \mathrm{~B}$ cells, $\mathrm{CeO}_{2}$ increases oxidative stress and induced the translocation of Nrf2 to the nucleus and increased HO-1 expression [23]. 
In studies by the same group, a non-metal oxide $\mathrm{PM}_{0.1}$ such as silicon dioxide (silica) also increases ROS production, translocation of Nrf2 and induction of antioxidant proteins [24]. In an animal model of daily intratracheal instillation of $\mathrm{TiO}_{2} \mathrm{NP}$, there was significant induction of Nrf2 mRNA and protein in the lung through 75 days; there was also significantly more HO-1 and the catalytic subunit glutamate-cysteine ligase (GCLC) levels, the rate-limiting enzyme involved in the synthesis of GSH [75]. Some of the long-term effects may dependent on Nrf2 expression in specific cell types. Li et al. showed that Nrf2 deficiency in dendritic cells (DCs) provoked a more severe allergic inflammation in the lung of mice after exposure to ovalbumin simultaneously with ambient $\mathrm{PM}_{0.1}$, suggesting that $\mathrm{Nrf} 2$ deficiency in DCs increases the adjuvant effect of $\mathrm{PM}_{0.1}$ on allergic sensitization [76]. Exposure to urban vehicular $\mathrm{PM}_{0.1}$ induces the expression of phase II enzymes (e.g., NQO1 and HO-1) and increases the expression and the nuclear translocation of Nrf2 in brain (cerebellum), liver, and lungs only in young (but not older) mice, suggesting that protection against oxidative stress caused by urban $\mathrm{PM}_{0.1}$ exposure decreases with age, which may contribute to the development of chronic and systemic disease [77].

\subsection{PI3K/Akt/mTOR}

Phosphoinositide 3-kinase (PI3K) serves as the upstream activator of protein kinase B (PKB, also known as Akt kinase), which together are involved in an intracellular signaling cascade that cumulatively have a pro-survival effect. The mammalian target of rapamycin (mTOR) is an evolutionarily conserved serine-threonine protein kinase and a member of the PI3K family that negatively regulates autophagy. Aberrant PI3K/Akt/mTOR signaling is evidenced in several pathologies, including atherosclerosis. Given the previously discussed role of autophagy in respect to $\mathrm{PM}_{0.1}$ exposure, coupled with the ability of the PI3K/Akt/mTOR signaling pathway, a next logical step would be to assume an association between this pathway and $\mathrm{PM}_{0.1}$ exposure. Indeed, Roy and colleagues illustrated the mechanism through which ZnO NPs induce macrophage cell death by downregulating PI3K/Akt/mTOR phosphorylation, which functionally leads to enhanced autophagic and apoptotic cell death [78]. Similar findings were illustrated by Duan et al. (2014) in response to endothelial cell exposure to silica NPs, the exposure to which results in an inhibition of PI3K/Akt/mTOR signaling and a subsequent increase in autophagic cell death [79]. Although few studies have examined the effects of ambient $\mathrm{PM}_{0.1}$ in vivo, Liu and colleagues (2011) addressed this by assessing the effects of exposure to functionalized single-walled nano-tubes. In vitro, these NPs resulted in changes in PI3K/Akt/mTOR signaling and in vivo resulted in acute lung injury [80]. Taken together, these studies illustrate activation of a common signaling pathway in response to different NPs.

\subsection{Transcription Factor EB (TFEB)}

Transcription factor EB (TFEB) is the master of the regulatory gene network (CLEAR) [81]. This transcription factor, as a global modulator of intracellular clearance and energy metabolism, lysosomal biogenesis, has provided new insight into the mechanism by which the cell responds to environmental stimuli $[48,82]$. TFEB is a master regulator of lysosomal biogenesis, autophagy and cell adaptation that regulates the expression of genes encoding lysosomal proteins $[83,84]$, the processing of lysosomal proteins and the expression of autophagy genes [82,85]. TFEB was proposed to be a coordinator of autophagy and lysosomal functions in cells exposed to PM [47]. Here, ceria NPs functionalized with different types of biocompatible coatings (e.g., $\mathrm{N}$-acetylglucosamine, polyethylene glycol and polyvinylpyrrolidone) activated TFEB-regulated genes of the lysosome-autophagy system. These investigators also showed that the array of differently functionalized ceria NPs enhanced autophagic clearance of proteolipid aggregates that accumulate as a result of inefficient function of the lysosome-autophagy system. Translocation of TFEB from the cytosol into the nucleus is a prerequisite for gene regulation and represents an example that this cellular process is induced by PM. There 
is currently no information on TFEB regulation by PM from other sources such as air pollution or cigarette smoke.

\section{Epigenetic Contribution to Pulmonary and Systemic Disease}

Toxicogenomics has emerged as a field that combines traditional toxicology with functional genomics to define adverse effects of environmental contaminants. Such characterization involves quantification of changes at the DNA and RNA level but more recently involves analysis of microRNA (miRNA) expression and other epigenetic changes including DNA methylation, histone modifications, and other non-coding RNAs. Epigenetics refers to heritable changes in gene expression without accompanying alterations in the DNA sequence [86]. Such epigenetic alterations can include DNA methylation, histone tail modification as well as non-coding RNA (ncRNA)-mediated events [87] and may underlie the pathogenesis of complex diseases associated with environmental exposure to $\mathrm{PM}_{0.1}$ (Figure 2).

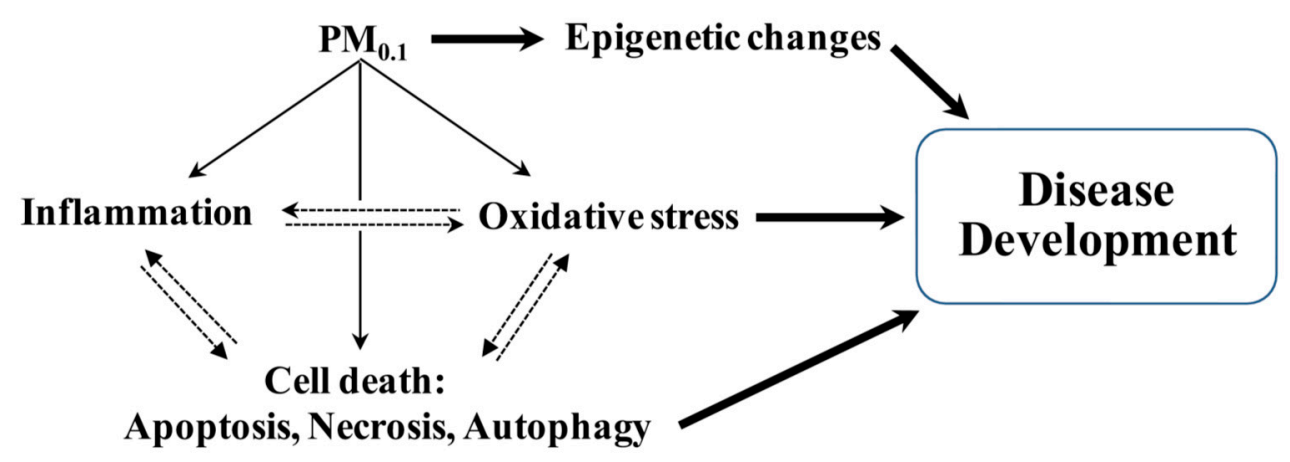

Figure 2. Intersecting pathogenic mechanisms converge to increase susceptibility to developing chronic cardiopumonary diseases assocoated with exposure to $\mathrm{PM}_{0.1}$.

\subsection{MicroRNA (miRNA)}

miRNAs constitute a large group of non-coding RNAs that downregulate protein expression by triggering translational repression and/or mRNA degradation [88]. miRNAs are synthesized as longer transcripts which are then processed by the ribonucleases Drosha and Dicer, giving rise to mature miRNAs. Mature miRNAs assemble with members of the argonaute protein family into miRNA-induced silencing complex. The miRNA directs the RNA-induced silencing complex (RISC) to target mRNAs for degradation [89]. Aberrant expression of miRNA is now implicated in many diseases, and there is increasing interest in the use of miRNA signatures as biomarkers for diseases such as cancer and COPD [90-93]. The most studied environmental factor for miRNA is smoking. Changes in miRNA levels in response to cigarette smoke exposure-the main cause of COPD for example-is well-noted in vitro as well as in vivo after smoke exposure and in individuals with COPD [90,94-96]. Changes in miRNA levels after exposure to diesel exhaust particles (DEP) are also evident in human lung cells [97]. As both cigarette smoke and diesel exhaust contains large amounts of $\mathrm{PM}_{0.1}[73,98]$, it remains to be seen whether these changes in miRNA are related to particle composition or size, especially in light of the chemical nature of complex mixtures (e.g., cigarette smoke, DEP). Thus, it is likely that $\mathrm{PM}_{0.1}$ contribute only a component towards the regulation of miRNA expression.

However, the effects of individual $\mathrm{PM}_{0.1}$ can also mediate changes in miRNA expression in experimental systems and may even be useful for detecting exposure to $\mathrm{PM}_{0.1}$ as potential biomarkers. Using AuNPs administered intravenously to adult Wistar rats, Chew and colleagues reported on the differential regulation of 23 blood miRNA levels, with signatures being both similar and different based on 1 week versus 2 months post-exposure [99]. It was noteworthy that some miRNA remained significantly changed at both time points including miR-146b, which was significantly decreased with exposure to AuNP. Members of the miR-146 family (miR-146a and miR-146b) are negative regulators 
of inflammation $[94,100,101]$ and are typically increased as a means to attenuate inflammatory protein expression (e.g., IL-8, COX-2). Thus it is interesting to speculate the NP-induced changes in anti-inflammatory miRNA such as those belonging to the miR-146 family, may significantly contribute to alterations in inflammation. Additional studies using $\mathrm{TiO}_{2}$ inhalation in mice has revealed significant changes in lung inflammatory cells (predominantly increased neutrophilia), cytokines and acute phase proteins [102]. This same study also performed miRNA expression profiling and reported that 55 miRNA in the lungs were also altered as a consequence of $\mathrm{TiO}_{2}$ exposure, including those associated with immunological responses such as miR-21 [102]. TiO $\mathrm{O}_{2}$ is not the only $\mathrm{PM}_{0.1}$ that can cause changes in miR-21. Carbon black NP also induced pulmonary expression of miR-21, as well as miR-135b and miR-146b, all of which were increased following exposure [103]. However, pulmonary administration of carbon black did not significantly alter cardiac miRNA expression. Moreover, incubation of mouse epidermal cells with Tungsten carbide-cobalt (WC-Co) NPs increased miR-21 [104]. It is intriguing that in the former study, miR-146b in the lung is increased, whereas it was decreased in the blood. Whether this difference in miR-146b levels is reflective of the $\mathrm{PM}_{0.1}$ used (AuNP versus carbon black), the species (rat versus mouse) or the target organ (blood versus lung) remains to be seen. While bioinformatic analysis in search of predicted miRNA target proteins (e.g., using TargetScan (http://www.targetscan.org/)) indicates potential targets of these miRNA, there remain exceedingly few studies to directly evaluate whether the $\mathrm{PM}_{0.1}$-induced changes in select miRNA directly regulate protein expression and hence contribute to pathogenic processes described above. Despite little evidence in the literature validating $\mathrm{PM}_{0.1}$-induced miRNA changes, miRNA expression profiles are offering potential as biomarkers of organ-specific damage. A recent example of this includes analysis of organ-specific miRNA such as miR-122, miR-192 and miR-194; miRNA that are highly expressed in the liver may also serve as marker of organ damage by silica NP. Administration of silica NP at a diameter of $70 \mathrm{~nm}$ induced severe liver damage in mice and significantly increased systemic miR-122 [105,106]. Thus, accumulating evidence supports that that environmental agents, including $\mathrm{PM}_{0.1}$, contribute significantly to alterations in miRNA levels.

\subsection{Long Non-Coding RNA (lncRNA)}

Long non-coding RNAs (lncRNAs) constitute a large of family of RNAs greater than 200 nucleotides long [107]. Originally, it was believed that lncRNA constituted "transcriptional noise," and thus only synthesized incidentally with the transcription of traditional protein-coding genes. Now it is known that lncRNAs possess a diverse repertoire of cellular functions, some of which may play crucial roles in the pathophysiology of air pollution-induced disease. First, lncRNAs can influence the transcription of protein-coding genes via antagonization of RNA polymerase II and the transcription initiation complex [108]. Second, lncRNAs regulate gene expression at the post-transcriptional level by masking splice sites on mRNAs [109], preventing miRNA binding, and even sequestering large numbers of miRNA species by functioning as "miRNA sponges" [110]. Finally, IncRNAs can influence the function of translated proteins via sequestering these proteins [111] and/or providing scaffolding for multi-protein complexes [112]. However, there remains limited information on the role lncRNAs play in response to particulate matter, including $\mathrm{PM}_{0.1}$. One study by Thai and colleagues revealed the lncRNA SCAL1 is induced in vitro in lung cancer cell lines by cigarette smoke extract (CSE). Further analysis of the mechanism revealed that CSE induced Nrf2-dependent binding to the promoter of SCAL1 for transcriptional upregulation and that SCAL1 was required for cell survival [113]. The contribution of this lncRNA—or that of others—in the pathogenesis of diseases associated with $\mathrm{PM}_{0.1}$ is unknown.

\subsection{DNA Methylation}

DNA methylation is one of the most-studied epigenetics events that can influence cell behavior by promoting or inhibiting transcription. It is also heritable by somatic cells after cell division, and is essential for embryogenesis, with methylation pattern changing to accommodate differentiation and 
development [114]. There are numerous studies that have examined epigenetic effects, specifically DNA methylation, in response to fine and ultrafine air pollution particles (reviewed in [87]). In workers exposed to $\mathrm{PM}_{10}$, for example, there was lower promoter methylation of inducible nitric oxide synthase (iNOS) [115]. Cigarette smoke has been widely studied as a model of epigenetic changes, where DNA hypermethylation of $\mathrm{CPG}$ islands in the promoter region of tumor suppressors and other genes has been described [116]. Moreover, long-term exposure to aerosol PM was negatively associated with global methylation of the DNA [115]. It is noteworthy that lower methylation of DNA is found in patients with cancer or cardiovascular disease [117], suggesting that lower DNA methylation is a possible mechanism by which exposure to $\mathrm{PM}_{0.1}$ can lead to the development of disease.

One of the pathways affected by environmentally-induced methylation involves the AhR and specifically, the AHRR. In addition to being a negative regulator of AhR activity (reviewed above), it has been suggested that the AHRR is a tumor suppressor and is downregulated in many types of cancer due to DNA hypermethylation [118]. The association between AHRR methylation/smoking remains the most convincing example of a relationship between environmental exposures and DNA methylation changes in humans [119]. In this light, there are numerous studies that have shown an association between smoking and AHRR methylation status [120], such that methylation changes occur early [121]. Furthermore, methylation levels are close in former smokers when compared to never smokers [122], suggesting some reversibility in the process. Decreased methylation of the AHRR in smokers is associated with decreased expression in lymphoblasts [120], is affected by maternal smoking [119], and may represent a biomarker of smoke exposure [121]. While at the time of this writing there is no information on the methylation status of the AHRR in response to other forms/sizes of PM (e.g., $\mathrm{PM}_{0.1}$ ), it is possible that AHRR methylation may be a general response rather than specific to cigarette smoke. In support of this, there is emerging evidence that several types of engineered $\mathrm{PM}_{0.1}$ can induce global DNA hypomethylation, including $\mathrm{SiO}_{2}$ in $\mathrm{HaCaT}$ cells, [123], and that hypermethylation of the poly-ADP-ribose polymerase-1 (PARP-1) promoter corresponds with decreased PARP-1 gene expression [124].

These long-term environmental exposures may also significantly impact the health of subsequent generations. Studies now indicate that maternal exposure to cigarette smoke, for example, impacts molecular pathways in newborns due to methylation of CpG sites, including the AhR pathway [125,126]. This epigenetic signature also persists into childhood when exposed in utero [127]. Such changes may impact disease susceptibility later in life. Studies using experimental models of asthma indicate that in utero exposure to smoke caused significant alterations in DNA methylation that was associated with features of asthma (airway hyperactivity, inflammation) [128]. With respect to air pollution, exposure to $\mathrm{PM}_{2.5}$ is associated with lower placental DNA methylation [129]. Furthermore, maternal exposure to combustion-derived $\mathrm{PM}_{0.1}$ enhances post-natal asthma development in mice by mechanisms speculated to be epigenetic in nature [130]. Additional studies to evaluate potential epigenetic changes associated with $\mathrm{PM}_{0.1}$ exposure are warranted.

\section{Conclusions}

Personal exposure to $\mathrm{PM}_{0.1}$ (ultrafine particles smaller than $100 \mathrm{~nm}$ ) occurs on a daily basis, and such chronic exposure is now associated with adverse health effects. Because of their extremely small size, $\mathrm{PM}_{0.1}$ are deposited deep into the lungs and subsequently distributed throughout the organism via the circulatory system, reaching secondary organs, such as the brain, heart and liver. At the cellular level, exposure to $\mathrm{PM}_{0.1}$ activates several signaling pathways (i.e., NF- $\mathrm{KB}, \mathrm{NADPH}$ oxidase) to orchestrate pathological responses characterized by production of inflammatory mediators and reactive oxygen species (ROS). This is followed by a cascade of events that lead to the death of cells by different mechanisms (apoptosis, necrosis, autophagy). Particle accumulation due to long-term exposure is thus associated with chronic inflammatory diseases such as COPD. PM $\mathrm{M}_{0.1}$ also may cause DNA mutations and epigenetic modifications, which can lead the affected cell to transform into cancer cells. Even though research on $\mathrm{PM}_{0.1}$ is almost 30 years old, further studies are needed to better 
understand the mechanisms of toxicity of inhaled urban $\mathrm{PM}_{0.1}$ to develop new preventative and/or therapeutic strategies to reduce the negative impact of $\mathrm{PM}_{0.1}$ on human health. Future studies of $\mathrm{PM}_{0.1}$ should be integrated with physical and chemical research to perform tailored experimental conditions, in addition to addressing key unknown mechanistic processes from air pollutant transformation before and after exposure, alteration on biological surfaces, physiological impacts and their ultimate impacts.

Acknowledgments: This work was supported by a Canada Foundation for Innovation Leaders Opportunity Fund (CFI-LOF); the Natural Sciences and Engineering Research Council of Canada (NSERC); and the Canadian Institute for Health Research (CIHR). Carolyn J. Baglole was supported by a salary award from the Fonds de recherche du Quebec-Sante (FRQ-S).

Conflicts of Interest: The authors declare no conflict of interest.

\section{References}

1. Paulin, L.; Hansel, N. Particulate air pollution and impaired lung function. F1000 Res. 2016, 5, 201. [CrossRef] [PubMed]

2. Valavanidis, A.; Fiotakis, K.; Vlachogianni, T. Airborne particulate matter and human health: Toxicological assessment and importance of size and composition of particles for oxidative damage and carcinogenic mechanisms. J. Environ. Sci. Health C Environ. Carcinog. Ecotoxicol. Rev. 2008, 26, 339-362. [CrossRef] [PubMed]

3. Nemmar, A.; Holme, J.A.; Rosas, I.; Schwarze, P.E.; Alfaro-Moreno, E. Recent advances in particulate matter and nanoparticle toxicology: A review of the in vivo and in vitro studies. BioMed Res. Int. 2013, 2013, 279371. [CrossRef] [PubMed]

4. Morakinyo, O.M.; Mokgobu, M.I.; Mukhola, M.S.; Hunter, R.P. Health outcomes of exposure to biological and chemical components of inhalable and respirable particulate matter. Int. J. Environ. Res. Public Health 2016, 13, 592. [CrossRef] [PubMed]

5. Aalapati, S.; Ganapathy, S.; Manapuram, S.; Anumolu, G.; Prakya, B.M. Toxicity and bio-accumulation of inhaled cerium oxide nanoparticles in CD1 mice. Nanotoxicology 2014, 8, 786-798. [CrossRef] [PubMed]

6. Mills, N.L.; Amin, N.; Robinson, S.D.; Anand, A.; Davies, J.; Patel, D.; de la Fuente, J.M.; Cassee, F.R.; Boon, N.A.; Macnee, W.; et al. Do inhaled carbon nanoparticles translocate directly into the circulation in humans? Am. J. Respir. Crit. Care Med. 2006, 173, 426-431. [CrossRef] [PubMed]

7. HEI Review Panel on Ultrafine Particles. Understanding the Health Effects of Ambient Ultrafine Particles; Health Effects Institute: Boston, MA, USA, 2013.

8. Baglole, C.J.; Ray, D.M.; Bernstein, S.H.; Feldon, S.E.; Smith, T.J.; Sime, P.J.; Phipps, R.P. More than structural cells, fibroblasts create and orchestrate the tumor microenvironment. Immunol. Investig. 2006, 35, 297-325. [CrossRef] [PubMed]

9. Alessandri, A.L.; Sousa, L.P.; Lucas, C.D.; Rossi, A.G.; Pinho, V.; Teixeira, M.M. Resolution of inflammation: Mechanisms and opportunity for drug development. Pharmacol. Ther. 2013, 139, 189-212. [CrossRef] [PubMed]

10. Aggarwal, B.B.; Shishodia, S.; Sandur, S.K.; Pandey, M.K.; Sethi, G. Inflammation and cancer: How hot is the link? Biochem. Pharmacol. 2006, 72, 1605-1621. [CrossRef] [PubMed]

11. de Souza, A.R.; Zago, M.; Eidelman, D.H.; Hamid, Q.; Baglole, C.J. Aryl hydrocarbon receptor (AhR) attenuation of subchronic cigarette smoke-induced pulmonary neutrophilia is associated with retention of nuclear RelB and suppression of intercellular adhesion molecule-1 (ICAM-1). Toxicol. Sci. 2014, 140, 204-223. [CrossRef] [PubMed]

12. Hetland, R.B.; Cassee, F.R.; Refsnes, M.; Schwarze, P.E.; Lag, M.; Boere, A.J.; Dybing, E. Release of inflammatory cytokines, cell toxicity and apoptosis in epithelial lung cells after exposure to ambient air particles of different size fractions. Toxicol. In Vitro 2004, 18, 203-212. [CrossRef]

13. Val, S.; Martinon, L.; Cachier, H.; Yahyaoui, A.; Marfaing, H.; Baeza-Squiban, A. Role of size and composition of traffic and agricultural aerosols in the molecular responses triggered in airway epithelial cells. Inhal. Toxicol. 2011, 23, 627-640. [PubMed] 
14. Steenhof, M.; Gosens, I.; Strak, M.; Godri, K.J.; Hoek, G.; Cassee, F.R.; Mudway, I.S.; Kelly, F.J.; Harrison, R.M.; Lebret, E.; et al. In vitro toxicity of particulate matter (PM) collected at different sites in the Netherlands is associated with PM composition, size fraction and oxidative potential-The RAPTES project. Part. Fibre Toxicol. 2011, 8, 26. [CrossRef] [PubMed]

15. Osornio-Vargas, A.R.; Bonner, J.C.; Alfaro-Moreno, E.; Martinez, L.; Garcia-Cuellar, C.; Ponce-de-Leon Rosales, S.; Miranda, J.; Rosas, I. Proinflammatory and cytotoxic effects of Mexico City air pollution particulate matter in vitro are dependent on particle size and composition. Environ. Health Perspect. 2003, 111, 1289-1293. [CrossRef] [PubMed]

16. Braakhuis, H.M.; Park, M.V.; Gosens, I.; De Jong, W.H.; Cassee, F.R. Physicochemical characteristics of nanomaterials that affect pulmonary inflammation. Part. Fibre Toxicol. 2014, 11, 18. [CrossRef] [PubMed]

17. Araujo, J.A.; Barajas, B.; Kleinman, M.; Wang, X.; Bennett, B.J.; Gong, K.W.; Navab, M.; Harkema, J.; Sioutas, C.; Lusis, A.J.; et al. Ambient particulate pollutants in the ultrafine range promote early atherosclerosis and systemic oxidative stress. Circ. Res. 2008, 102, 589-596. [CrossRef] [PubMed]

18. Pedata, P.; Bergamasco, N.; D’Anna, A.; Minutolo, P.; Servillo, L.; Sannolo, N.; Balestrieri, M.L. Apoptotic and proinflammatory effect of combustion-generated organic nanoparticles in endothelial cells. Toxicol. Lett. 2013, 219, 307-314. [CrossRef] [PubMed]

19. Noel, A.; Xiao, R.; Perveen, Z.; Zaman, H.M.; Rouse, R.L.; Paulsen, D.B.; Penn, A.L. Incomplete lung recovery following sub-acute inhalation of combustion-derived ultrafine particles in mice. Part. Fibre Toxicol. 2016, 13, 10. [CrossRef] [PubMed]

20. Lundborg, M.; Dahlen, S.E.; Johard, U.; Gerde, P.; Jarstrand, C.; Camner, P.; Lastbom, L. Aggregates of ultrafine particles impair phagocytosis of microorganisms by human alveolar macrophages. Environ. Res. 2006, 100, 197-204. [CrossRef] [PubMed]

21. Kaspar, J.W.; Niture, S.K.; Jaiswal, A.K. Nrf2:INrf2 (Keap1) signaling in oxidative stress. Free Radic. Biol. Med. 2009, 47, 1304-1309. [CrossRef] [PubMed]

22. Tang, Y.; Shen, Y.; Huang, L.; Lv, G.; Lei, C.; Fan, X.; Lin, F.; Zhang, Y.; Wu, L.; Yang, Y. In vitro cytotoxicity of gold nanorods in A549 cells. Environ. Toxicol. Pharmacol. 2015, 39, 871-878. [CrossRef] [PubMed]

23. Eom, H.J.; Choi, J. Oxidative stress of $\mathrm{CeO}_{2}$ nanoparticles via p38-Nrf-2 signaling pathway in human bronchial epithelial cell, Beas-2B. Toxicol. Lett. 2009, 187, 77-83. [CrossRef] [PubMed]

24. Eom, H.J.; Choi, J. Oxidative stress of silica nanoparticles in human bronchial epithelial cell, Beas-2B. Toxicol. In Vitro 2009, 23, 1326-1332. [CrossRef] [PubMed]

25. Kim, H.R.; Kim, M.J.; Lee, S.Y.; Oh, S.M.; Chung, K.H. Genotoxic effects of silver nanoparticles stimulated by oxidative stress in human normal bronchial epithelial (BEAS-2B) cells. Mutat. Res. 2011, 726, 129-135. [CrossRef] [PubMed]

26. Avalos, A.; Haza, A.I.; Mateo, D.; Morales, P. Effects of silver and gold nanoparticles of different sizes in human pulmonary fibroblasts. Toxicol. Mech. Methods 2015, 25, 1-9. [CrossRef] [PubMed]

27. Periasamy, V.S.; Athinarayanan, J.; Al-Hadi, A.M.; Juhaimi, F.A.; Alshatwi, A.A. Effects of titanium dioxide nanoparticles isolated from confectionery products on the metabolic stress pathway in human lung fibroblast cells. Arch. Environ. Contam. Toxicol. 2015, 68, 521-533. [CrossRef] [PubMed]

28. Montiel-Davalos, A.; Ventura-Gallegos, J.L.; Alfaro-Moreno, E.; Soria-Castro, E.; Garcia-Latorre, E.; Cabanas-Moreno, J.G.; del Pilar Ramos-Godinez, M.; Lopez-Marure, R. $\mathrm{TiO}_{2}$ nanoparticles induce dysfunction and activation of human endothelial cells. Chem. Res. Toxicol. 2012, 25, 920-930. [CrossRef] [PubMed]

29. Alinovi, R.; Goldoni, M.; Pinelli, S.; Campanini, M.; Aliatis, I.; Bersani, D.; Lottici, P.P.; Iavicoli, S.; Petyx, M.; Mozzoni, P.; et al. Oxidative and pro-inflammatory effects of cobalt and titanium oxide nanoparticles on aortic and venous endothelial cells. Toxicol. In Vitro 2015, 29, 426-437. [CrossRef] [PubMed]

30. Petrick, L.; Rosenblat, M.; Paland, N.; Aviram, M. Silicon dioxide nanoparticles increase macrophage atherogenicity: Stimulation of cellular cytotoxicity, oxidative stress, and triglycerides accumulation. Environ. Toxicol. 2014, 31, 713-723. [CrossRef] [PubMed]

31. Mo, Y.; Wan, R.; Feng, L.; Chien, S.; Tollerud, D.J.; Zhang, Q. Combination effects of cigarette smoke extract and ambient ultrafine particles on endothelial cells. Toxicol. In Vitro 2012, 26, 295-303. [CrossRef] [PubMed]

32. Li, N.; Sioutas, C.; Cho, A.; Schmitz, D.; Misra, C.; Sempf, J.; Wang, M.; Oberley, T.; Froines, J.; Nel, A. Ultrafine particulate pollutants induce oxidative stress and mitochondrial damage. Environ. Health Perspect. 2003, 111, 455-460. [CrossRef] [PubMed] 
33. Ryter, S.W.; Kim, H.P.; Hoetzel, A.; Park, J.W.; Nakahira, K.; Wang, X.; Choi, A.M. Mechanisms of cell death in oxidative stress. Antioxid. Redox Signal. 2007, 9, 49-89. [CrossRef] [PubMed]

34. Brauner, E.V.; Forchhammer, L.; Moller, P.; Simonsen, J.; Glasius, M.; Wahlin, P.; Raaschou-Nielsen, O.; Loft, S. Exposure to ultrafine particles from ambient air and oxidative stress-induced DNA damage. Environ. Health Perspect. 2007, 115, 1177-1182. [CrossRef] [PubMed]

35. Zhong, C.Y.; Zhou, Y.M.; Smith, K.R.; Kennedy, I.M.; Chen, C.Y.; Aust, A.E.; Pinkerton, K.E. Oxidative injury in the lungs of neonatal rats following short-term exposure to ultrafine iron and soot particles. J. Toxicol. Environ. Health A 2010, 73, 837-847. [CrossRef] [PubMed]

36. Zhang, X.; Staimer, N.; Gillen, D.L.; Tjoa, T.; Schauer, J.J.; Shafer, M.M.; Hasheminassab, S.; Pakbin, P.; Vaziri, N.D.; Sioutas, C.; et al. Associations of oxidative stress and inflammatory biomarkers with chemically-characterized air pollutant exposures in an elderly cohort. Environ. Res. 2016, 150, 306-319. [CrossRef] [PubMed]

37. Dalton, T.P.; Shertzer, H.G.; Puga, A. Regulation of gene expression by reactive oxygen. Annu. Rev. Pharmacol. Toxicol. 1999, 39, 67-101. [CrossRef] [PubMed]

38. Sambandam, B.; Devasena, T.; Islam, V.I.; Prakhya, B.M. Characterization of coal fly ash nanoparticles and their induced in vitro cellular toxicity and oxidative DNA damage in different cell lines. Indian J. Exp. Biol. 2015, 53, 585-593. [PubMed]

39. Chan, J.K.; Kodani, S.D.; Charrier, J.G.; Morin, D.; Edwards, P.C.; Anderson, D.S.; Anastasio, C.; van Winkle, L.S. Age-specific effects on rat lung glutathione and antioxidant enzymes after inhaling ultrafine soot. Am. J. Respir. Cell Mol. Biol. 2013, 48, 114-124. [CrossRef] [PubMed]

40. Jouan-Lanhouet, S.; Riquet, F.; Duprez, L.; Vanden Berghe, T.; Takahashi, N.; Vandenabeele, P. Necroptosis, in vivo detection in experimental disease models. Semin. Cell Dev. Biol. 2014, 35, 2-13. [CrossRef] [PubMed]

41. Foldbjerg, R.; Olesen, P.; Hougaard, M.; Dang, D.A.; Hoffmann, H.J.; Autrup, H. PVP-coated silver nanoparticles and silver ions induce reactive oxygen species, apoptosis and necrosis in THP-1 monocytes. Toxicol. Lett. 2009, 190, 156-162. [CrossRef] [PubMed]

42. Pan, Y.; Leifert, A.; Ruau, D.; Neuss, S.; Bornemann, J.; Schmid, G.; Brandau, W.; Simon, U.; Jahnen-Dechent, W. Gold nanoparticles of diameter $1.4 \mathrm{~nm}$ trigger necrosis by oxidative stress and mitochondrial damage. Small 2009, 5, 2067-2076. [CrossRef] [PubMed]

43. Lu, S.; Zhang, W.; Zhang, R.; Liu, P.; Wang, Q.; Shang, Y.; Wu, M.; Donaldson, K. Comparison of cellular toxicity caused by ambient ultrafine particles and engineered metal oxide nanoparticles. Part. Fibre Toxicol. 2015, 12, 5. [CrossRef] [PubMed]

44. Sydlik, U.; Bierhals, K.; Soufi, M.; Abel, J.; Schins, R.P.; Unfried, K. Ultrafine carbon particles induce apoptosis and proliferation in rat lung epithelial cells via specific signaling pathways both using EGF-R. Am. J. Physiol. Lung Cell Mol. Physiol. 2006, 291, L725-L733. [CrossRef] [PubMed]

45. Kaewamatawong, T.; Shimada, A.; Okajima, M.; Inoue, H.; Morita, T.; Inoue, K.; Takano, H. Acute and subacute pulmonary toxicity of low dose of ultrafine colloidal silica particles in mice after intratracheal instillation. Toxicol. Pathol. 2006, 34, 958-965. [CrossRef] [PubMed]

46. He, C.; Klionsky, D.J. Regulation mechanisms and signaling pathways of autophagy. Annu. Rev. Genet. 2009, 43, 67-93. [CrossRef] [PubMed]

47. Song, W.; Soo Lee, S.; Savini, M.; Popp, L.; Colvin, V.L.; Segatori, L. Ceria nanoparticles stabilized by organic surface coatings activate the lysosome-autophagy system and enhance autophagic clearance. ACS Nano 2014, 8, 10328-10342. [CrossRef] [PubMed]

48. Neibert, K.D.; Maysinger, D. Mechanisms of cellular adaptation to quantum dots-the role of glutathione and transcription factor EB. Nanotoxicology 2012, 6, 249-262. [CrossRef] [PubMed]

49. Li, J.J.; Hartono, D.; Ong, C.N.; Bay, B.H.; Yung, L.Y. Autophagy and oxidative stress associated with gold nanoparticles. Biomaterials 2010, 31, 5996-6003. [CrossRef] [PubMed]

50. Chen, Z.H.; Wu, Y.F.; Wang, P.L.; Wu, Y.P.; Li, Z.Y.; Zhao, Y.; Zhou, J.S.; Zhu, C.; Cao, C.; Mao, Y.Y.; et al. Autophagy is essential for ultrafine particle-induced inflammation and mucus hyperproduction in airway epithelium. Autophagy 2016, 12, 297-311. [CrossRef] [PubMed]

51. Grossmann, M.; Nakamura, Y.; Grumont, R.; Gerondakis, S. New insights into the roles of ReL/NF-kB transcription factors in immune function, hemopoiesis and human disease. Int. J. Biochem. Cell Biol. 1999, 31, 1209-1219. [CrossRef] 
52. Martey, C.A.; Pollock, S.J.; Turner, C.K.; O’Reilly, K.M.; Baglole, C.J.; Phipps, R.P.; Sime, P.J. Cigarette smoke induces cyclooxygenase-2 and microsomal prostaglandin E2 synthase in human lung fibroblasts: Implications for lung inflammation and cancer. Am. J. Physiol. Lung Cell. Mol. Physiol. 2004, 287, L981-L991. [CrossRef] [PubMed]

53. Liu, X.; Sun, J. Endothelial cells dysfunction induced by silica nanoparticles through oxidative stress via JNK/P53 and NF-KB pathways. Biomaterials 2010, 31, 8198-8209. [CrossRef] [PubMed]

54. Manna, P.; Ghosh, M.; Ghosh, J.; Das, J.; Sil, P.C. Contribution of nano-copper particles to in vivo liver dysfunction and cellular damage: Role of $\mathrm{I \kappa} \mathrm{B} \alpha / \mathrm{NF}-\mathrm{kB}, \mathrm{MAPKs}$ and mitochondrial signal. Nanotoxicology 2012, 6, 1-21. [CrossRef] [PubMed]

55. Nishanth, R.P.; Jyotsna, R.G.; Schlager, J.J.; Hussain, S.M.; Reddanna, P. Inflammatory responses of RAW 264.7 macrophages upon exposure to nanoparticles: Role of ROS-NFKB signaling pathway. Nanotoxicology 2011, 5, 502-516. [CrossRef] [PubMed]

56. Wu, W.; Samet, J.M.; Peden, D.B.; Bromberg, P.A. Phosphorylation of p65 is required for zinc oxide nanoparticle-induced interleukin 8 expression in human bronchial epithelial cells. Environ. Health Perspect. 2010, 118, 982-987. [CrossRef] [PubMed]

57. Tsai, C.Y.; Lu, S.L.; Hu, C.W.; Yeh, C.S.; Lee, G.B.; Lei, H.Y. Size-dependent attenuation of TLR9 signaling by gold nanoparticles in macrophages. J. Immunol. 2012, 188, 68-76. [CrossRef] [PubMed]

58. Bren, G.D.; Solan, N.J.; Miyoshi, H.; Pennington, K.N.; Pobst, L.J.; Paya, C.V. Transcription of the RelB gene is regulated by NF-kB. Oncogene 2001, 20, 7722-7733. [CrossRef] [PubMed]

59. Beinke, S.; Ley, S.C. Functions of NF-kB1 and NF-kB2 in immune cell biology. Biochem. J. 2004, 382 Pt 2, 393-409. [CrossRef] [PubMed]

60. Dejardin, E. The alternative NF- $\mathrm{B}$ p pathway from biochemistry to biology: Pitfalls and promises for future drug development. Biochem. Pharmacol. 2006, 72, 1161-1179. [CrossRef] [PubMed]

61. Kim, J.Y.; Morgan, M.; Kim, D.G.; Lee, J.Y.; Bai, L.; Lin, Y.; Liu, Z.G.; Kim, Y.S. TNF $\alpha$ induced noncanonical NF- $\mathrm{KB}$ activation is attenuated by RIP1 through stabilization of TRAF2. J. Cell Sci. 2011, 124 Pt 4, 647-656. [CrossRef] [PubMed]

62. Yoza, B.K.; Hu, J.Y.; Cousart, S.L.; Forrest, L.M.; McCall, C.E. Induction of RelB participates in endotoxin tolerance. J. Immunol. 2006, 177, 4080-4085. [CrossRef] [PubMed]

63. Oliver, K.M.; Lenihan, C.R.; Bruning, U.; Cheong, A.; Laffey, J.G.; McLoughlin, P.; Taylor, C.T.; Cummins, E.P. Hypercapnia induces cleavage and nuclear localization of RelB protein, giving insight into $\mathrm{CO}_{2}$ sensing and signaling. J. Biol. Chem. 2012, 287, 14004-14011. [CrossRef] [PubMed]

64. Brustle, A.; Brenner, D.; Knobbe, C.B.; Lang, P.A.; Virtanen, C.; Hershenfield, B.M.; Reardon, C.; Lacher, S.M.; Ruland, J.; Ohashi, P.S.; et al. The NF- $\mathrm{B}$ regulator MALT1 determines the encephalitogenic potential of Th17 cells. J. Clin. Investig. 2012, 122, 4698-4709. [CrossRef] [PubMed]

65. Lo, D.; Quill, H.; Burkly, L.; Scott, B.; Palmiter, R.D.; Brinster, R.L. A recessive defect in lymphocyte or granulocyte function caused by an integrated transgene. Am. J. Pathol. 1992, 141, 1237-1246. [PubMed]

66. Weih, F.; Carrasco, D.; Durham, S.K.; Barton, D.S.; Rizzo, C.A.; Ryseck, R.P.; Lira, S.A.; Bravo, R. Multiorgan inflammation and hematopoietic abnormalities in mice with a targeted disruption of RelB, a member of the NF-кB/Rel family. Cell 1995, 80, 331-340. [CrossRef]

67. McMillan, D.H.; Baglole, C.J.; Thatcher, T.H.; Maggirwar, S.; Sime, P.J.; Phipps, R.P. Lung-targeted overexpression of the NF-кB member RelB inhibits cigarette smoke-induced inflammation. Am. J. Pathol. 2011, 179, 125-133. [CrossRef] [PubMed]

68. Mimura, J.; Ema, M.; Sogawa, K.; Fujii-Kuriyama, Y. Identification of a novel mechanism of regulation of Ah (dioxin) receptor function. Genes Dev. 1999, 13, 20-25. [CrossRef] [PubMed]

69. Hosoya, T.; Harada, N.; Mimura, J.; Motohashi, H.; Takahashi, S.; Nakajima, O.; Morita, M.; Kawauchi, S.; Yamamoto, M.; Fujii-Kuriyama, Y. Inducibility of cytochrome P450 1A1 and chemical carcinogenesis by benzo[a]pyrene in AhR repressor-deficient mice. Biochem. Biophys. Res. Commun. 2008, 365, 562-567. [CrossRef] [PubMed]

70. Baglole, C.J.; Maggirwar, S.B.; Gasiewicz, T.A.; Thatcher, T.H.; Phipps, R.P.; Sime, P.J. The aryl hydrocarbon receptor attenuates tobacco smoke-induced cyclooxygenase-2 and prostaglandin production in lung fibroblasts through regulation of the NF-кB family member RelB. J. Biol. Chem. 2008, 283, 28944-28957. [CrossRef] [PubMed] 
71. Hecht, E.; Zago, M.; Sarill, M.; Rico de Souza, A.; Gomez, A.; Matthews, J.; Hamid, Q.; Eidelman, D.H.; Baglole, C.J. Aryl hydrocarbon receptor-dependent regulation of miR-196a expression controls lung fibroblast apoptosis but not proliferation. Toxicol. Appl. Pharmacol. 2014, 280, 511-525. [CrossRef] [PubMed]

72. Sarill, M.; Zago, M.; Sheridan, J.A.; Nair, P.; Matthews, J.; Gomez, A.; Roussel, L.; Rousseau, S.; Hamid, Q.; Eidelman, D.H.; et al. The aryl Hydrocarbon receptor suppresses cigarette-smoke-induced oxidative stress in association with dioxin response element (DRE)-independent regulation of sulfiredoxin 1. Free Radic. Biol. Med. 2015, 89, 342-357. [CrossRef] [PubMed]

73. Van Dijk, W.D.; Gopal, S.; Scheepers, P.T. Nanoparticles in cigarette smoke; real-time undiluted measurements by a scanning mobility particle sizer. Anal. Bioanal. Chem. 2011, 399, 3573-3578. [CrossRef] [PubMed]

74. Chan, J.K.; Vogel, C.F.; Baek, J.; Kodani, S.D.; Uppal, R.S.; Bein, K.J.; Anderson, D.S.; Van Winkle, L.S. Combustion derived ultrafine particles induce cytochrome P-450 expression in specific lung compartments in the developing neonatal and adult rat. Am. J. Physiol. Lung Cell. Mol. Physiol. 2013, 304, L665-L677. [CrossRef] [PubMed]

75. Sun, Q.; Tan, D.; Zhou, Q.; Liu, X.; Cheng, Z.; Liu, G.; Zhu, M.; Sang, X.; Gui, S.; Cheng, J.; et al. Oxidative damage of lung and its protective mechanism in mice caused by long-term exposure to titanium dioxide nanoparticles. J. Biomed. Mater. Res. A 2012, 100, 2554-2562. [CrossRef] [PubMed]

76. Li, N.; Wang, M.; Barajas, B.; Sioutas, C.; Williams, M.A.; Nel, A.E. Nrf2 deficiency in dendritic cells enhances the adjuvant effect of ambient ultrafine particles on allergic sensitization. J. Innate Immun. 2013, 5, 543-554. [CrossRef] [PubMed]

77. Zhang, H.; Liu, H.; Davies, K.J.; Sioutas, C.; Finch, C.E.; Morgan, T.E.; Forman, H.J. Nrf2-regulated phase II enzymes are induced by chronic ambient nanoparticle exposure in young mice with age-related impairments. Free Radic. Biol. Med. 2012, 52, 2038-2046. [CrossRef] [PubMed]

78. Roy, R.; Singh, S.K.; Chauhan, L.K.; Das, M.; Tripathi, A.; Dwivedi, P.D. Zinc oxide nanoparticles induce apoptosis by enhancement of autophagy via PI3K/Akt/mTOR inhibition. Toxicol. Lett. 2014, 227, $29-40$. [CrossRef] [PubMed]

79. Duan, J.; Yu, Y.; Li, Y.; Wang, J.; Geng, W.; Jiang, L.; Li, Q.; Zhou, X.; Sun, Z. Silica nanoparticles induce autophagy and endothelial dysfunction via the PI3K/Akt/mTOR signaling pathway. Int. J. Nanomed. 2014, 9, 5131-5141. [CrossRef] [PubMed]

80. Liu, H.L.; Zhang, Y.L.; Yang, N.; Zhang, Y.X.; Liu, X.Q.; Li, C.G.; Zhao, Y.; Wang, Y.G.; Zhang, G.G.; Yang, P.; et al. A functionalized single-walled carbon nanotube-induced autophagic cell death in human lung cells through Akt-TSC2-mTOR signaling. Cell Death Dis. 2011, 2, e159. [CrossRef] [PubMed]

81. Napolitano, G.; Ballabio, A. TFEB at a glance. J. Cell Sci. 2016, 129, 2475-2481. [CrossRef] [PubMed]

82. Settembre, C.; Di Malta, C.; Polito, V.A.; Garcia Arencibia, M.; Vetrini, F.; Erdin, S.; Erdin, S.U.; Huynh, T.; Medina, D.; Colella, P.; et al. TFEB links autophagy to lysosomal biogenesis. Science 2011, 332, 1429-1433. [CrossRef] [PubMed]

83. Sardiello, M.; Palmieri, M.; di Ronza, A.; Medina, D.L.; Valenza, M.; Gennarino, V.A.; di Malta, C.; Donaudy, F.; Embrione, V.; Polishchuk, R.S.; et al. A gene network regulating lysosomal biogenesis and function. Science 2009, 325, 473-477. [CrossRef] [PubMed]

84. Palmieri, M.; Impey, S.; Kang, H.; di Ronza, A.; Pelz, C.; Sardiello, M.; Ballabio, A. Characterization of the CLEAR network reveals an integrated control of cellular clearance pathways. Hum. Mol. Genet. 2011, 20, 3852-3866. [CrossRef] [PubMed]

85. Song, W.; Wang, F.; Savini, M.; Ake, A.; di Ronza, A.; Sardiello, M.; Segatori, L. TFEB regulates lysosomal proteostasis. Hum. Mol. Genet. 2013, 22, 1994-2009. [CrossRef] [PubMed]

86. Reamon-Buettner, S.M.; Mutschler, V.; Borlak, J. The next innovation cycle in toxicogenomics: Environmental epigenetics. Mutat. Res. 2008, 659, 158-165. [CrossRef] [PubMed]

87. Stoccoro, A.; Karlsson, H.L.; Coppede, F.; Migliore, L. Epigenetic effects of nano-sized materials. Toxicology 2013, 313, 3-14. [CrossRef] [PubMed]

88. Keene, J.D. RNA regulons: Coordination of post-transcriptional events. Nat. Rev. Genet. 2007, 8, 533-543. [CrossRef] [PubMed]

89. Inui, M.; Martello, G.; Piccolo, S. MicroRNA control of signal transduction. Nat. Rev. Mol. Cell Biol. 2010, 11, 252-263. [CrossRef] [PubMed] 
90. Sheridan, J.A.; Zago, M.; Nair, P.; Li, P.Z.; Bourbeau, J.; Tan, W.C.; Hamid, Q.; Eidelman, D.H.; Benedetti, A.L.; Baglole, C.J. Decreased expression of the NF- $\mathrm{kB}$ family member RelB in lung fibroblasts from Smokers with and without COPD potentiates cigarette smoke-induced COX-2 expression. Respir. Res. 2015, 16, 1-16. [CrossRef] [PubMed]

91. Gallardo, E.; Navarro, A.; Vinolas, N.; Marrades, R.M.; Diaz, T.; Gel, B.; Quera, A.; Bandres, E.; Garcia-Foncillas, J.; Ramirez, J.; et al. miR-34a as a prognostic marker of relapse in surgically resected non-small-cell lung cancer. Carcinogenesis 2009, 30, 1903-1909. [CrossRef] [PubMed]

92. Kosaka, N.; Iguchi, H.; Ochiya, T. Circulating microRNA in body fluid: A new potential biomarker for cancer diagnosis and prognosis. Cancer Sci. 2010, 101, 2087-2092. [CrossRef] [PubMed]

93. Leidinger, P.; Keller, A.; Borries, A.; Huwer, H.; Rohling, M.; Huebers, J.; Lenhof, H.P.; Meese, E. Specific peripheral miRNA profiles for distinguishing lung cancer from COPD. Lung Cancer 2011, 74, 41-47. [CrossRef] [PubMed]

94. Zago, M.; Rico de Souza, A.; Hecht, E.; Rousseau, S.; Hamid, Q.; Eidelman, D.H.; Baglole, C.J. The NF-кB family member RelB regulates microRNA miR-146a to suppress cigarette smoke-induced COX-2 protein expression in lung fibroblasts. Toxicol. Lett. 2014, 226, 107-116. [CrossRef] [PubMed]

95. Izzotti, A.; Calin, G.A.; Arrigo, P.; Steele, V.E.; Croce, C.M.; de Flora, S. Downregulation of microRNA expression in the lungs of rats exposed to cigarette smoke. FASEB J. 2009, 23, 806-812. [CrossRef] [PubMed]

96. Pottelberge, G.R.; Mestdagh, P.; Bracke, K.R.; Thas, O.; Durme, Y.M.; Joos, G.F.; Vandesompele, J.; Brusselle, G.G. MicroRNA expression in induced sputum of smokers and patients with chronic obstructive pulmonary disease. Am. J. Respir. Crit. Care Med. 2011, 183, 898-906. [CrossRef] [PubMed]

97. Jardim, M.J.; Fry, R.C.; Jaspers, I.; Dailey, L.; Diaz-Sanchez, D. Disruption of microRNA expression in human airway cells by diesel exhaust particles is linked to tumorigenesis-associated pathways. Environ. Health Perspect. 2009, 117, 1745-1751. [CrossRef] [PubMed]

98. Ronkko, T.; Pirjola, L.; Ntziachristos, L.; Heikkila, J.; Karjalainen, P.; Hillamo, R.; Keskinen, J. Vehicle engines produce exhaust nanoparticles even when not fueled. Environ. Sci. Technol. 2014, 48, 2043-2050. [CrossRef] [PubMed]

99. Chew, W.S.; Poh, K.W.; Siddiqi, N.J.; Alhomida, A.S.; Yu, L.E.; Ong, W.Y. Short- and long-term changes in blood miRNA levels after nanogold injection in rats-Potential biomarkers of nanoparticle exposure. Biomarkers 2012, 17, 750-757. [CrossRef] [PubMed]

100. Taganov, K.D.; Boldin, M.P.; Chang, K.J.; Baltimore, D. NF-kB-dependent induction of microRNA miR-146, an inhibitor targeted to signaling proteins of innate immune responses. Proc. Natl. Acad. Sci. USA 2006, 103, 12481-12486. [CrossRef] [PubMed]

101. Echavarria, R.; Mayaki, D.; Neel, J.C.; Harel, S.; Sanchez, V.; Hussain, S.N. Angiopoietin-1 inhibits toll-like receptor 4 signalling in cultured endothelial cells: Role of miR-146b-5p. Cardiovasc. Res. 2015, 106, 465-477. [CrossRef] [PubMed]

102. Halappanavar, S.; Jackson, P.; Williams, A.; Jensen, K.A.; Hougaard, K.S.; Vogel, U.; Yauk, C.L.; Wallin, H. Pulmonary response to surface-coated nanotitanium dioxide particles includes induction of acute phase response genes, inflammatory cascades, and changes in microRNAs: A toxicogenomic study. Environ. Mol. Mutagen. 2011, 52, 425-439. [CrossRef] [PubMed]

103. Bourdon, J.A.; Saber, A.T.; Halappanavar, S.; Jackson, P.A.; Wu, D.; Hougaard, K.S.; Jacobsen, N.R.; Williams, A.; Vogel, U.; Wallin, H.; et al. Carbon black nanoparticle intratracheal installation results in large and sustained changes in the expression of miR-135b in mouse lung. Environ. Mol. Mutagen. 2012, 53, 462-468. [CrossRef] [PubMed]

104. Hou, L.; Bowman, L.; Meighan, T.G.; Shi, X.; Ding, M. Induction of miR-21-PDCD4 signaling by tungsten carbide-cobalt nanoparticles in JB6 cells involves ROS-mediated MAPK pathways. J. Environ. Pathol. Toxicol. Oncol. 2013, 32, 41-51. [CrossRef] [PubMed]

105. Nabeshi, H.; Yoshikawa, T.; Matsuyama, K.; Nakazato, Y.; Arimori, A.; Isobe, M.; Tochigi, S.; Kondoh, S.; Hirai, T.; Akase, T.; et al. Amorphous nanosilicas induce consumptive coagulopathy after systemic exposure. Nanotechnology 2012, 23, 045101. [CrossRef] [PubMed]

106. Nagano, T.; Higashisaka, K.; Kunieda, A.; Iwahara, Y.; Tanaka, K.; Nagano, K.; Abe, Y.; Kamada, H.; Tsunoda, S.; Nabeshi, H.; et al. Liver-specific microRNAs as biomarkers of nanomaterial-induced liver damage. Nanotechnology 2013, 24, 405102. [CrossRef] [PubMed] 
107. Geisler, S.; Coller, J. RNA in unexpected places: Long non-coding RNA functions in diverse cellular contexts. Nat. Rev. Mol. Cell Biol. 2013, 14, 699-712. [CrossRef] [PubMed]

108. Martianov, I.; Ramadass, A.; Serra Barros, A.; Chow, N.; Akoulitchev, A. Repression of the human dihydrofolate reductase gene by a non-coding interfering transcript. Nature 2007, 445, 666-670. [CrossRef] [PubMed]

109. Faghihi, M.A.; Zhang, M.; Huang, J.; Modarresi, F.; van der Brug, M.P.; Nalls, M.A.; Cookson, M.R.; St-Laurent, G., 3rd; Wahlestedt, C. Evidence for natural antisense transcript-mediated inhibition of microRNA function. Genome Biol. 2010, 11, R56. [CrossRef] [PubMed]

110. Granados-Riveron, J.T.; Aquino-Jarquin, G. The complexity of the translation ability of circRNAs. Biochim. Biophys. Acta 2016, 1859, 1245-1251. [CrossRef] [PubMed]

111. Yin, Q.F.; Yang, L.; Zhang, Y.; Xiang, J.F.; Wu, Y.W.; Carmichael, G.G.; Chen, L.L. Long noncoding RNAs with snoRNA ends. Mol. Cell 2012, 48, 219-230. [CrossRef] [PubMed]

112. Dobson, L.; Nyitray, L.; Gaspari, Z. A conserved charged single $\alpha$-helix with a putative steric role in paraspeckle formation. RNA 2015, 21, 2023-2029. [CrossRef] [PubMed]

113. Thai, P.; Statt, S.; Chen, C.H.; Liang, E.; Campbell, C.; Wu, R. Characterization of a novel long noncoding RNA, SCAL1, induced by cigarette smoke and elevated in lung cancer cell lines. Am. J. Respir. Cell Mol. Biol. 2013, 49, 204-211. [CrossRef] [PubMed]

114. Bollati, V.; Baccarelli, A. Environmental epigenetics. Heredity 2010, 105, 105-112. [CrossRef] [PubMed]

115. Tarantini, L.; Bonzini, M.; Apostoli, P.; Pegoraro, V.; Bollati, V.; Marinelli, B.; Cantone, L.; Rizzo, G.; Hou, L.; Schwartz, J.; et al. Effects of particulate matter on genomic DNA methylation content and iNOS promoter methylation. Environ. Health Perspect. 2009, 117, 217-222. [CrossRef] [PubMed]

116. Lyn-Cook, L.; Word, B.; George, N.; Lyn-Cook, B.; Hammons, G. Effect of cigarette smoke condensate on gene promoter methylation in human lung cells. Tob. Induc. Dis. 2014, 12, 15. [CrossRef] [PubMed]

117. Castro, R.; Rivera, I.; Struys, E.A.; Jansen, E.E.; Ravasco, P.; Camilo, M.E.; Blom, H.J.; Jakobs, C.; Tavares de Almeida, I. Increased homocysteine and $S$-adenosylhomocysteine concentrations and DNA hypomethylation in vascular disease. Clin. Chem. 2003, 49, 1292-1296. [CrossRef] [PubMed]

118. Zudaire, E.; Cuesta, N.; Murty, V.; Woodson, K.; Adams, L.; Gonzalez, N.; Martinez, A.; Narayan, G.; Kirsch, I.; Franklin, W.; et al. The aryl hydrocarbon receptor repressor is a putative tumor suppressor gene in multiple human cancers. J. Clin. Investig. 2008, 118, 640-650. [CrossRef] [PubMed]

119. Novakovic, B.; Ryan, J.; Pereira, N.; Boughton, B.; Craig, J.M.; Saffery, R. Postnatal stability, tissue, and time specific effects of AHRR methylation change in response to maternal smoking in pregnancy. Epigenetics 2014, 9, 377-386. [CrossRef] [PubMed]

120. Monick, M.M.; Beach, S.R.; Plume, J.; Sears, R.; Gerrard, M.; Brody, G.H.; Philibert, R.A. Coordinated changes in AHRR methylation in lymphoblasts and pulmonary macrophages from smokers. Am. J. Med. Genet. B Neuropsychiatr. Genet. 2012, 159B, 141-151. [CrossRef] [PubMed]

121. Philibert, R.A.; Beach, S.R.; Brody, G.H. Demethylation of the aryl hydrocarbon receptor repressor as a biomarker for nascent smokers. Epigenetics 2012, 7, 1331-1338. [CrossRef] [PubMed]

122. Zeilinger, S.; Kuhnel, B.; Klopp, N.; Baurecht, H.; Kleinschmidt, A.; Gieger, C.; Weidinger, S.; Lattka, E.; Adamski, J.; Peters, A.; et al. Tobacco smoking leads to extensive genome-wide changes in DNA methylation. PLoS ONE 2013, 8, e63812. [CrossRef] [PubMed]

123. Gong, C.; Tao, G.; Yang, L.; Liu, J.; Liu, Q.; Zhuang, Z. $\mathrm{SiO}_{2}$ nanoparticles induce global genomic hypomethylation in HaCaT cells. Biochem. Biophys. Res. Commun. 2010, 397, 397-400. [CrossRef] [PubMed]

124. Gong, C.; Tao, G.; Yang, L.; Liu, J.; Liu, Q.; Li, W.; Zhuang, Z. Methylation of PARP-1 promoter involved in the regulation of nano-SiO 2 -induced decrease of PARP-1 mRNA expression. Toxicol. Lett. 2012, 209, 264-269. [CrossRef] [PubMed]

125. Rotroff, D.M.; Joubert, B.R.; Marvel, S.W.; Haberg, S.E.; Wu, M.C.; Nilsen, R.M.; Ueland, P.M.; Nystad, W.; London, S.J.; Motsinger-Reif, A. Maternal smoking impacts key biological pathways in newborns through epigenetic modification in Utero. BMC Genom. 2016, 17, 976. [CrossRef] [PubMed]

126. Joubert, B.R.; Haberg, S.E.; Nilsen, R.M.; Wang, X.; Vollset, S.E.; Murphy, S.K.; Huang, Z.; Hoyo, C.; Midttun, O.; Cupul-Uicab, L.A.; et al. 450K epigenome-wide scan identifies differential DNA methylation in newborns related to maternal smoking during pregnancy. Environ. Health Perspect. 2012, 120, 1425-1431. [CrossRef] [PubMed] 
127. Ladd-Acosta, C.; Shu, C.; Lee, B.K.; Gidaya, N.; Singer, A.; Schieve, L.A.; Schendel, D.E.; Jones, N.; Daniels, J.L.; Windham, G.C.; et al. Presence of an epigenetic signature of prenatal cigarette smoke exposure in childhood. Environ. Res. 2016, 144, 139-148. [CrossRef] [PubMed]

128. Lee, J.W.; Jaffar, Z.; Pinkerton, K.E.; Porter, V.; Postma, B.; Ferrini, M.; Holian, A.; Roberts, K.; Cho, Y.H. Alterations in DNA methylation and airway hyperreactivity in response to in utero exposure to environmental tobacco smoke. Inhal. Toxicol. 2015, 27, 724-730. [CrossRef] [PubMed]

129. Janssen, B.G.; Godderis, L.; Pieters, N.; Poels, K.; Kicinski, M.; Cuypers, A.; Fierens, F.; Penders, J.; Plusquin, M.; Gyselaers, W.; et al. Placental DNA hypomethylation in association with particulate air pollution in early life. Part. Fibre Toxicol. 2013, 10, 22. [CrossRef] [PubMed]

130. Wang, P.; You, D.; Saravia, J.; Shen, H.; Cormier, S.A. Maternal exposure to combustion generated PM inhibits pulmonary Th1 maturation and concomitantly enhances postnatal asthma development in offspring. Part. Fibre Toxicol. 2013, 10, 29. [CrossRef] [PubMed]

(C) 2017 by the authors; licensee MDPI, Basel, Switzerland. This article is an open access article distributed under the terms and conditions of the Creative Commons Attribution (CC BY) license (http:/ / creativecommons.org/licenses/by/4.0/). 